\title{
STOCKHOLM \\ NATURAL RADIOCARBON MEASUREMENTS IV
}

\author{
LARS G. ENGSTRAND and H. GÖTE ÖSTLUND
}

Radioactive Dating Laboratory*, Frescati, Stockholm 50, Sweden

\author{
INTRODUCTION
}

This paper is a direct continuation of the third dating list (Stockholm III), and the entire technique is virtually unchanged, using one $0.5-1$ and one 1.0-1 3 atm $\mathrm{CO}_{2}$ proportional counter. Ages are calculated according to the recommendation given in the introduction of this book, and $\delta \mathrm{C}^{13}$ has been measured for unknown samples and for the different $\mathrm{CO}_{2}$ preparations of the NBS oxalic-acid standard. Since the numerical relationship between the $\mathrm{C}^{14}$ activity of our old oak standard and that of NBS was valid for a $\delta C^{13}$ value of almost exactly -19 for the NBS preparation in question, it still holds true that all dates given in Stockholm I, II and III can be converted to the new scale by subtracting 55 yr. The NBS preparation St-532 measured by Craig (1961) having a $\delta \mathrm{C}^{13}$ value of -17.2 is only one of several preparations with values between -17 and -20 . Age figures are given in $\mathrm{C}^{14} \mathrm{yr}$ before A.D. 1950; the half life for $\mathrm{C}^{14}$ is taken as $5568 \pm 30 \mathrm{yr}$.

\section{ACKNOWLEDGMENTS}

We are indebted to Mrs. Ingrid Almstedt for having excellently performed most of the routine work; as usual Dr. R. Ryhage and his staff at the massspectrometric laboratory of the Karolinska Institute, have been of very great help, having made the $\mathrm{C}^{13}$ determinations.

\section{SAMPLE DESCRIPTIONS}

\section{GEOLOGIC SAMPLES-SWEDEN}

\section{Limhamn series}

\section{A. Postglacial Strandlines}

Wood from a piece of peat, ca. $25 \mathrm{~cm}$ thick, found at depth of $5.6 \mathrm{~m}$ in the harbor of Limhamn, City of Malmö, Skåne $\left(55^{\circ} 36^{\prime} \mathrm{N}\right.$ Lat, $12^{\circ} 56^{\prime} \mathrm{E}$ Long). The piece of peat has been pollen-analytically dated to the transition between Boreal and Atlantic times, and correlated with similar peat found in the harbor at depth of $8 \mathrm{~m}$. The peat there is covered by marine clay gyttja. The pollen-analytical dating of the peat gives a maximum age estimated to 7500-8000 yr for the time when the Tapes-Litorina-transgression reached the level now situated $8 \mathrm{~m}$ below recent sealevel at Limhamn (Persson, 1962). Coll. by G. Fredriksson, Limhamn; subm. by Tage Nilsson and Gösta Persson, Inst. of Quaternary Geol., Lund Univ.

\section{St-720. Limhamn harbor, sample $B$}

Fragment of a small branch of Salix, lying horizontally in the upper part of the peat.

* Operated by Royal Academy of Antiquities, Geol. Survey of Sweden and, beginning 1962, Stockholm University. 
St-732. Limhamn harbor, sample D

$7990 \pm 160$

Fragment of a slightly larger branch of Salix (wood with bark), lying horizontally in the upper part of the peat.

\section{Ösbysjön series}

Three samples of sediments from the lake ösbysjön $\left(59^{\circ} 24^{\prime} \mathrm{N}\right.$ Lat, $18^{\circ}$ 04' E Long), ca. $7.5 \mathrm{~m}$ above sealevel, Djursholm, Uppland. Samples were cut out from two $36 \mathrm{~mm}$ diam cores. Subm. by Magnus Fries, Dept. of Plant Ecol., Univ. of Uppsala, Sweden. To be described by the submitter (1962).

St-616. Clay gyttja

$4600 \pm 120$

$410-430 \mathrm{~cm}$ below the sediment surface. This sample reflects the time when signs first appeared indicating basin had started to become isolated from the Baltic.

St-642. Fibrous algal gyttja

$2070 \pm 80$

$232-246 \mathrm{~cm}$ below the sediment surface. Sample dates the final isolation of the lake from the Baltic. Indications of agriculture increase above this level in the pollen diagram.

St-628. Lake gyttja

$1015 \pm 70$

118-138 cm below the sediment surface (supplement core). Sample dates a marked rise in the Picea pollen curve and a corresponding decrease of the Quercus pollen curve.

\section{Harmånger series}

Sediment samples from a number of small bogs at different alt around Harmånger $\left(61^{\circ} 50^{\prime}\right.$ to $62^{\circ} 00^{\prime} \mathrm{N}$ Lat, $17^{\circ} 03^{\prime}$ to $17^{\circ} 23^{\prime} \mathrm{E}$ Long) $24 \mathrm{~km} \mathrm{~N}$ of Hudiksvall, Hälsingland. Dated as a part of an investigation on crustal uplift. All samples were taken in connection with the isolation level, except for St. 778 and 777 taken in recurrence surfaces. Coll. 1960 by C. Larsson; subm. by G. Lundqvist, Geol. Survey of Sweden, Stockholm. Each sample is named after the bog in question.

St-708. Nordanmyran : 9

$2535 \pm 110$

St-747. Nordanmyran: 10

$3270 \pm 105$

St-716. Fjällmyran: 11

$3970 \pm 100$

St-770. Fjällmyran: 12

$4315 \pm 145$

St-776. At Strömsbruk: 13

$945 \pm 130$

St-709. At Strömsbruk: 14

$1400 \pm 90$

St-771. At Strömsbruk: 15

$1810 \pm 140$

St-717. Smälskmyran: 16

$2140 \pm 80$

St-772. Smälskmyran: 17

$2310 \pm 140$ 
St-710. Stormyran SW Högen: 18

$6260 \pm 100$

St-749. Stormyran SW Högen: 19

$6750 \pm 140$

St-718. Gränsmyran: 20

$5495 \pm 115$

St-769. Gränsmyran: 21

$5810 \pm 140$

St-778. Gränsmyran: 22

$755 \pm 100$

St-777. Gränsmyran: 23

$1055 \pm 130$

St-753. Stormyran N Lake Sörsjön: 24

$6295 \pm 185$

St-754. Stormyran N Lake Sörsjön : 25

$6780 \pm 155$

St-711. At Lake Idsjön : 26

$4585 \pm 90$

St-773. At Lake Idsjön : 28

$\mathbf{5 4 1 5} \pm \mathbf{1 8 0}$

St-781. Rödjebergsmyren: 29

$5890 \pm 160$

St-719. Rödjebergsmyren: 30

$6000 \pm 140$

St-774. Rödjebergsmyren: 31

$6530 \pm 150$

St-712. Bergkärrsmyran: 32

$\mathbf{5 5 9 0} \pm \mathbf{9 0}$

St-750. Bergkärrsmyran : 33

$7160 \pm 140$

St-713. Knåptjärn: 34

$4050 \pm 65$

St-755. Knåptjärn: 35

St-714. Gammelbomyran: 36

$\mathbf{5 7 4 5} \pm \mathbf{1 5 0}$

St-775. Gammelbomyran: 37

$3480 \pm 80$

St-715. Ståltjärn : 38

$3670 \pm 150$

St-779. Ståltjärn : 39

$6375 \pm 90$

St-782. Ståltjärn: 40

$\mathbf{7 0 7 0} \pm \mathbf{2 0 0}$

$6940 \pm 160$

\section{Jordbärsmyren series}

B. Recurrence Surfaces

Peat samples from profiles in the bog Jordbärsmyren $\left(60^{\circ} 18^{\prime} \mathrm{N}\right.$ Lat, $16^{\circ}$ $56^{\prime} \mathrm{E}$ Long), $3 \mathrm{~km} \mathrm{NE}$ of Gysinge, Gästrikland, analyzed as a part of an investigation of palynologic interest, especially the study of the recurrence surfaces. Coll. 1959 by S. Holmberg; subm. by G. Lundqvist. Bp numbers indicate drilling hole number. Depth given is below surface of the bog.

$\begin{array}{lllllr}\text { St-543. } & \text { Jordbärsmyren } & 1, \text { Bp } & 9: 170 \mathrm{~cm} & 850 \pm 90 \\ \text { St-544. } & \text { Jordbärsmyren } & 2, \text { Bp } & 9: 200 \mathrm{~cm} & 1070 \pm 80 \\ \text { St-545. } & \text { Jordbärsmyren } & \text { 3, Bp } & 9: 225 \mathrm{~cm} & 1950 \pm 75 \\ \text { St-546. } & \text { Jordbärsmyren } & 4, \text { Bp } & 9: 290 \mathrm{~cm} & 1900 \pm 85\end{array}$


St-582. Jordbärsmyren $5, B$ p: $330 \mathrm{~cm}$

$$
\begin{aligned}
& 3450 \pm 80 \\
& 3690 \pm 120 \\
& 4140 \pm 100 \\
& 4550 \pm 110 \\
& 1230 \pm 75 \\
& 1450 \pm 75 \\
& 1250 \pm 85 \\
& 1350 \pm 75
\end{aligned}
$$

St-612. Jordbärsmyren 7, Bp $9: 350 \mathrm{~cm}$

St-611. Jordbärsmyren 9, Bp 9: $360 \mathrm{~cm}$

St-583. Jordbärsmyren 13, Bp 9: $400 \mathrm{~cm}$

St-563. Jordbärsmyren 14, Bp $5: 170 \mathrm{~cm}$

St-564. Jordbärsmyren 15, Bp 5: $200 \mathrm{~cm}$

St-565. Jordbärsmyren 31, Bp 20: $70 \mathrm{~cm}$

\begin{tabular}{|c|c|c|}
\hline St-655. & Högmossen $\quad$ 1, Bp 22: $150 \mathrm{~cm}$ & $1145 \pm 60$ \\
\hline St-656. & Högmossen 2, Bp 22: $160 \mathrm{~cm}$ & $1280 \pm 90$ \\
\hline St-658. & Högmossen $5, B_{p} 22: 310 \mathrm{~cm}$ & $2215 \pm 7$ \\
\hline St-670. & Högmossen 6, Bp 22: $330 \mathrm{~cm}$ & $2785 \pm$ \\
\hline St-723. & Högmossen 7, Bp 22: $380 \mathrm{~cm}$ & $\mathbf{3 0 8 0} \pm 10$ \\
\hline St-725. & Högmossen 9, Bp 22: $440 \mathrm{~cm}$ & $3705 \pm 90$ \\
\hline St-671. & Högmossen 10, Bp 22: $480 \mathrm{~cm}$ & $3475 \pm$ \\
\hline St-672. & Högmossen 13, Bp 22: $575 \mathrm{~cm}$ & $4700 \pm$ \\
\hline St-673. & Högmossen 14, Bp 14: $125 \mathrm{~cm}$ & $1135 \pm$ \\
\hline St-674. & Högmossen 15, Bp 14: $160 \mathrm{~cm}$ & $1485 \pm$ \\
\hline St-675. & Högmossen 18, Bp 14: $245 \mathrm{~cm}$ & $2000 \pm$ \\
\hline St-677. & Högmossen 22, Bp 14: $400 \mathrm{~cm}$ & $3145 \pm$ \\
\hline St-678. & Högmossen 23, Bp 14: $430 \mathrm{~cm}$ & $\mathbf{3 7 8 0} \pm \mathbf{1 0 0}$ \\
\hline St-679. & Högmossen 26, Bp 26: $110 \mathrm{~cm}$ & $810 \pm$ \\
\hline St-680. & Högmossen 27, Bp 26: $130 \mathrm{~cm}$ & $1090 \pm$ \\
\hline St-726. & Högmossen 35, Bp 26: $350 \mathrm{~cm}$ & $\mathbf{3 0 7 0} \pm \mathbf{1}$ \\
\hline St-727. & Högmossen 26, Bp 26: $370 \mathrm{~cm}$ & $3175 \pm 1$ \\
\hline St-728. & Högmossen 38, Bp 26: $405 \mathrm{~cm}$ & $3220 \pm$ \\
\hline St-729. & Högmossen 46, Bp 1 : $20 \mathrm{~cm}$ & $165 \pm$ \\
\hline
\end{tabular}

St-566. Jordbärsmyren 32, Bp 20 : $100 \mathrm{~cm}$

Högmossen series

Peat samples from profiles in the raised bog at Högmossen $\left(61^{\circ} 00^{\prime} \mathrm{N}\right.$ Lat, $17^{\circ} 01^{\prime}$ E Long), W of Axmar, Gästrikland. Coll. 1960 by S. Holmberg; subm. by G. Lundqvist. Dated as part of an investigation on recurrence surfaces and of palynologic interest. Bp indicates drilled sampling hole number, $\mathrm{cm}$ figures are depth below surface of the bog. 
St-724. Högmossen 47, Bp 1: $30 \mathrm{~cm} \quad 766 \pm 65$

St-604. Norrtjärn $\quad \mathbf{3 7 8 0} \pm 90$

Peat from the little bog at Norrjärn $\left(61^{\circ} 24^{\prime} \mathrm{N}\right.$ Lat, $16^{\circ} 53^{\prime} \mathrm{E}$ Long $)$, $12 \mathrm{~km}$ WNW of Söderhamn at depth of $265-275 \mathrm{~cm}$ below the surface in a presumed recurrence surface. Coll. 1959 by C. Larsson; subm. by G. Lundqvist.

Ånn series

Samples from the peatbog at Klocka $\left(62^{\circ} 18^{\prime} \mathrm{N}\right.$ Lat, $12^{\circ} 28^{\prime} \mathrm{E}$ Long $)$, Ånn, Jämtland. All samples, except St-600, were wood from pine stumps imbedded at various levels, and were dated for their palynologic interest, especially the development of the recurrence surfaces. Coll. 1959 and subm. by Jan Lundqvist, Geol. Survey of Sweden.

St-571. Ånn C 1

$4450 \pm 80$

Pine stump layer $100 \mathrm{~cm}$ below surface $700 \mathrm{~m}$ from eastern edge of the bog. This level probably corresponds to a recurrence surface.

St-614. Ånn C 2

$8420 \pm 110$ as St-571.

Pine stump from the bottom layer, $230 \mathrm{~cm}$ below surface, same location

St-600. Ånn C 9

$8280 \pm 110$

Peat from the same point as St-614.

St-601. Ånn C 4

$3920 \pm 80$

Pine stump layer covered with a thin bed of alluvial sand within the peat, and situated $40 \mathrm{~cm}$ below surface, $2350 \mathrm{~m}$ from the eastern edge of the bog.

St-570. Ånn C 5

$6130 \pm 100$

Pine stump layer $100 \mathrm{~cm}$ below surface probably indicating a recurrence surface. Sampling point located $1500 \mathrm{~m}$ from eastern edge of the bog.

St-569. Ånn C 6

$8290 \pm 100$

Pine stump from bottom layer at $150 \mathrm{~cm}$; same location as St-570 above.

St-568. Ånn C 10

$4700 \pm 80$

Pine-stump layer at $75 \mathrm{~cm}$, close to the $\mathrm{E}$ edge of bog. The level probably indicates a recurrence surface.

St-615. Ånn C 11

$6120 \pm 100$

Pine stump from bottom layer at $150 \mathrm{~cm}$; same location as St-568.

\section{Various Geologic Problems}

\section{Hisinge Tunnel series}

Samples of marine clay, containing organic material, coll. by drilling holes while surveying for the construction of the Hisinge Tunnel under the river Göta Älv ( $57^{\circ} 43^{\prime} \mathrm{N}$ Lat, $10^{\circ} 58^{\prime} \mathrm{E}$ Long), city of Göteborg. The holes reaching to a depth of $93 \mathrm{~m}$ revealed a stratigraphy similar to that of the Ingebäck 
series (Stockholm III). Both series are described by the submitter, F. Brotzen (1961), Geol. Survey of Sweden. Depths are m below mean sealevel.

St-697. Hisinge Tunnel: 29-31 m $9185 \pm 140$

Isolated plant remains from the core, obtained by washing with distilled water. Geologic dating is Late Glacial II.

St-606. Hisinge Tunnel : $36 \mathrm{~m}$

St-607. Hisinge Tunnel : $56 \mathrm{~m}$

St-610. Hisinge Tunnel : $78 \mathrm{~m}$

St-609. Hisinge Tunnel: 89 m

$$
\begin{aligned}
& 14,930 \pm 160 \\
& 28,700 \begin{array}{r}
+2150 \\
-1670
\end{array} \\
& 27,500 \quad \begin{array}{r}
+1050 \\
-900
\end{array} \\
& 28,500+1100
\end{aligned}
$$

Comment (F.B.) : samples St-607, 610, 609 belong to interstadial sediments. St-606 originates from Late Glacial-I sediments.

St-524. Agnesberg

$11,000 \pm 120$

Sample of mollusc shells collected from Late-Glacial deposits near Agnesberg $\left(57^{\circ} 47^{\prime} \mathrm{N}\right.$ Lat, $12^{\circ} 00^{\prime} \mathrm{E}$ Long), $8 \mathrm{~km} \mathrm{~N}$ of Göteborg, $3 \mathrm{~km} \mathrm{~S}$ of Ingebäck in Göta Älv valley. Measured to check the reliability of this type of material. Subm. and described by F. Brotzen (1961). Comment (L.E., G.ö.) : shells were leached in acid, and after discarding the first portion (A) of gas, gas samples corresponding to intermediate $(B$, age $10,980 \pm 130)$ and inner layers $(\mathrm{C}$, age $11,010 \pm 130)$ were measured.

\section{Kyrkf järden series}

A $90 \mathrm{~cm}$ sediment core from the bottom of Kyrkfjärden $\left(59^{\circ} 26^{\prime} \mathrm{N}\right.$ Lat, $18^{\circ} 11^{\prime}$ E Long), a land-locked arm of the Stockholm skerry system. A high, narrow threshold and a permanently stratified salinity profile have created stagnancy in the deeper levels which probably extended back a considerable length of time. The core, from depth $16 \mathrm{~m}$, consists of dark gray-green gyttja. Lowest sample shows clear microvarves. Coll. 1959 and subm. by F. Manheim, Geol. Survey of Sweden.

St-572. Kyrkf järden 2

$880 \pm 85$

$2-13 \mathrm{~cm}$ below top of core.

St-573. Kyrkfjärden 3 $2580 \pm 120$

$56-70 \mathrm{~cm}$ below top of core.

St-574. Kyrkfjärden 4

$2950 \pm 110$

$77-90 \mathrm{~cm}$ below top of core.

St-748. Älvdalsåsen

$8870 \pm 120$

Wood of Pinus Silvestris found in river deposits, covered by solifluction soil at Älvdalsåsen $\left(61^{\circ} 15^{\prime} \mathrm{N}\right.$ Lat, $13^{\circ} 43^{\prime} \mathrm{E}$ Long), $10 \mathrm{~km} \mathrm{SSE}$ of Trängslet, 
Dalarna. Coll. 1961 and subm. by C. G. Wenner, Dept. of Quaternary Geol., Stockholm Univ.

St-599. Näsviken

Wood of Juniperus communis, from gravel at a depth of $8 \mathrm{~m}$ in a partly till-covered esker at Näsviken $\left(63^{\circ} 51^{\prime} \mathrm{N}\right.$ Lat, $15^{\circ} 32^{\prime} \mathrm{E}$ Long), Strömsund, Ström parish, Jämtland. Till-covered sediments are common in this area. It is not known if they are interglacial, or were covered by till at a Late-Glacial occasional ice advance. Coll. 1959 and subm. by Jan Lundqvist. Comment (L.E.) : $3 \sigma$ confidence in the age limit figure.

St-529. Målke C 1

$3280 \pm 110$

Peat from a moor close to Mount Måke $\left(66^{\circ} 28^{\prime} \mathrm{N}\right.$ Lat, $16^{\circ} 08^{\prime} \mathrm{E}$ Long), Arjeplog parish, Lappland. Sample was collected inside a terminal moraine belonging to an abandoned cirque, at a depth of $70 \mathrm{~cm}$ immediately above the moraine surface. It should date the end of the melting process of the former cirque glacier. Coll. 1959 and subm. by Lennart Vilborg, Dept. of Geog., Stockholm Univ.

\section{Dry fir series}

This series was part of a study on postglacial variations of the upper limit of a Pinus forest, caused by climatic changes. All samples consist of well preserved Pinus stumps partly revealed by erosion from the coverage of present vegetation at alt above the present-day forest-line. Subm. by G. Lundqvist. Another part of this series has been dated previously (Stockholm II) and was rescribed by G. Lundqvist (1959).

St-520. Abisko 2

$5620 \pm 100$

Location: an area $\mathrm{S}$ of Abisko Tourist Hotel at Lake Torneträsk $\left(68^{\circ} 20^{\prime}\right.$ N Lat, $18^{\circ} 43^{\prime}$ E Long) Lappland, alt $525 \mathrm{~m}$ above sealevel. Coll. 1959 by $\mathrm{G}$. Sandberg.

St-521. Abisko 3

$6130 \pm 115$

Same data as St-520, but alt $575 \mathrm{~m}$.

St-522. Abisko 4

$5175 \pm 100$

Same data as St-521.

St-523. Abisko 5

$3900 \pm 80$

Same data as St-520, but alt $530 \mathrm{~m}$.

St-538. Kvikkjokk 1

$6430 \pm 100$

Location: on Mount Ruoutevare ( $67^{\circ} 00^{\prime} \mathrm{N}$ Lat, $17^{\circ} 43^{\prime}$ E Long), Lappland, alt $576 \mathrm{~m}$. Coll. by G. Lundqvist.

St-539. Kvikkjokk 2

$6810 \pm 110$

Same data as St-538. 
St-541. Strimasund 1

$4485 \pm 80$

Location: close to Strimasund border patrol station $\left(66^{\circ} 10^{\prime} \mathrm{N}\right.$ Lat, $14^{\circ}$ 53’ E Long), Lappland, alt 550 m. Coll. by S. af Ekenstam.

St-621. Strimasund 2

$2690 \pm 80$

Same data as St-541, but coll. by G. Lundqvist.

St-623. Dåkkejaure 8

$6630 \pm 120$

Location: just $\mathrm{N}$ of Mount Ammarfjället ( $66^{\circ} 10^{\prime} \mathrm{N}$ Lat, $15^{\circ} 38^{\prime} \mathrm{E}$ Long), Lappland, alt $664 \mathrm{~m}$. Coll. by G. Bexell.

St-645. Steukajokk 3

$\mathbf{5 3 1 5} \pm \mathbf{8 5}$

Location: the same as St-623, alt $819 \mathrm{~m}$.

St-540. Kelottijärvi

$\mathbf{5 4 1 0} \pm 100$

Location: NW of Karesuando ( $68^{\circ} 30^{\prime} \mathrm{N}$ Lat, $14^{\circ} 00^{\prime} \mathrm{E}$ Long), Lappland, alt $369.5 \mathrm{~m}$. Coll. by late Dr. G. Ekström.

\section{St-687. Gurkbäcken}

Location: $\mathrm{N}$ of Tärnaby ( $65^{\circ} 48^{\prime} \mathrm{N}$ Lat, $15^{\circ} 20^{\prime} \mathrm{E}$ Long), Lappland, alt $620 \mathrm{~m}$. Coll. by K. Nilsson.

St-536. Dyllen

$265 \pm 90$

Recently fallen dry fir SW of Lake Grövelsjön $\left(62^{\circ} 02^{\prime} \mathrm{N}\right.$ Lat, $12^{\circ} 15^{\prime} \mathrm{E}$ Long), Dalarna, alt $820 \mathrm{~m}$. Coll. by G. Lindgren.

II. GEOLOGIC SAMPLES-OTHER COUNTRIES

\section{Hanaizumi series}

Wood fragment from profiles in the Hanaizumi bed at Kanamori $\left(38^{\circ}\right.$ $51^{\prime} \mathrm{N}$ Lat, $140^{\circ} 55^{\prime} \mathrm{E}$ Long), Hanaizumi-machi, $70 \mathrm{~km} \mathrm{~N}$ of Sendai, NE Japan. This bed is interesting for its mammalian deposits. Coll., subm. and preliminary description by the Kanto Loam Research Group (1961).

St-476. Hanaizumi 4

Uppermost part of Zone 7.

St-531. Hanaizumi 9

Lower part of Zone 8.

St-533. Hanaizumi 10

Zone 9.

\section{St-534. Hanaizumi 11}

$21,430 \pm 800$

$$
16,050 \pm 170
$$

$$
28,080+1250
$$

Average $35,000+\mathbf{2 0 0 0}$

Zone 13. Sample was divided into two parts. Part A was treated only with acid for carbonate removal before burning. Part B was carefully treated with an acid-alkali-acid cycle for removal of younger humus.

St-534 A. Without pretreatment

$34,500 \begin{array}{r}+3000 \\ -2000\end{array}$ 
St-534 B. With pretreatment

Comment (L.E., G.Ö.) : N.B., owing to the strong asymmetry of the error of this age, there is ca. $2 \%$ probability that the sample is more than $40,000 \mathrm{yr}$ old.

\section{St-676. Valkeissuo}

$7610 \pm 115$

Carex peat underneath a bed of littoral sand, $170 \mathrm{~cm}$ thick, at Valkeissuo $\left(62^{\circ} 53^{\prime} \mathrm{N}\right.$ Lat, $27^{\circ} 41^{\prime} \mathrm{E}$ Long), Kuopio parish, Finland. Alt $94.2 \mathrm{~m} ; 12.2 \mathrm{~m}$ above Lake Kallavesi. The Valkeissuo bog was submerged by transgression of Lake Kallavesi (Kotilainen 1953; Donner 1957). Coll. 1953 by M. Mansala and A. Rönty; subm. by Veikko Okko, Dept. of Geog., Helsinki Univ.

\section{St-689. Heposuo}

$5500 \pm 100$

Limnic gyttja (mud) interbedded in terrestrial peat, Kuopio Parish $\left(62^{\circ}\right.$ 54.6' $\mathrm{N}$ Lat, $27^{\circ} 56.5^{\prime} \mathrm{E}$ Long), Finland. Alt $94.5 \mathrm{~m} ; 12.5 \mathrm{~m}$ above Lake Kallavesi. The Heposuo bog was submerged by a transgression of Kallavesi during the postglacial climatic optimum (Okko, 1948, Donner, 1957). Coll. 1960 and subm. by Veikko Okko.

\section{St-527. Tuusula}

$4600 \pm 115$

Roots of black alder (Alnus glutinosa) from the Isokorpi bog, Ruotsinkylä, Tuusula $\left(60^{\circ} 22^{\prime} \mathrm{N}\right.$ Lat, $25^{\circ} 02^{\prime} \mathrm{E}$ Long) . Imbedded in beach-sand at alt 51.5 m. According to Sauramo $(1954,1958)$ the roots are remains of a forest submerged by the Ancylus or Echeneis transgression of the Baltic Sea. The supposed age of the roots is 8000 yr B.P. Coll., subm. and desc. by Veikko Okko (1960).

\section{ARCHAEOLOGIC SAMPLES SWEDEN}

\section{A. History of Iron Manufacturing}

\section{Osmund forges series}

Charcoal imbedded in slag from ancient iron manufacturing furnaces, socalled osmund forges. Subm. by G. Lundqvist, Geol. Survey of Sweden.

St-642. Tjärnåshyttan

$1860 \pm 90$

Pieces of slag from osmund forge found at Tjärnåshyttan $\left(60^{\circ} 31^{\prime} \mathrm{N}\right.$ Lat, $16^{\circ} 24^{\prime}$ E Long), $10 \mathrm{~km} \mathrm{SW}$ of Storvik, Gästrikland. Coll. by G. Lundqvist.

\section{St-640. Dammsjön}

$1415 \pm 130$

Pieces of osmund forge slag found just $\mathrm{N}$ of Lake Dammsjön $\left(60^{\circ} 26^{\prime} \mathrm{N}\right.$ Lat, $16^{\circ} 26^{\prime} \mathrm{E} \mathrm{Long),} \mathrm{ca.} 20 \mathrm{~km} \mathrm{SSW}$ of Storvik, Gästrikland. Coll. by G. Lundqvist.

St-643. Åsmundhyttan

$1980 \pm 100$

Pieces of osmund slag from a slag heap at Åsmundhyttan $\left(60^{\circ} 29^{\prime} \mathrm{N}\right.$ Lat, $16^{\circ} 27^{\prime}$ E Long), $12 \mathrm{~km} \mathrm{~S}$ of Storvik, Gästrikland. Coll. by P. Engqvist. Note that the name of the community means "osmund forge." 
St-644. Vall

$1640 \pm 85$

A fairly large heap of slag at Vall $\left(60^{\circ} 31^{\prime} \mathrm{N}\right.$ Lat, $16^{\circ} 24^{\prime} \mathrm{E}$ Long), ca. 11 km SSW of Storvik, Gästrikland. Coll. by P. Engqvist.

St-707. Gävle

$760 \pm 75$

Slag on an ancient grave field just NE of the city of Gävle $\left(60^{\circ} 4 \mathrm{l}^{\prime} \mathrm{N}\right.$ Lat, $17^{\circ} 07^{\prime}$ E Long), Gästrikland.

\section{Falun Copper Mines series}

Samples of peat and wood within lower layers of old mineral waste, and underlying material collected and investigated in order to date the beginning and earliest period of the mining activity in Falun Copper Mines, Falu Gruva $\left(60^{\circ} 36^{\prime} \mathrm{N}\right.$ Lat, $15^{\circ} 36^{\prime} \mathrm{E}$ Long), Falun, Dalarna. Coll. by G. Lundqvist and C. Larsson; subm. by Stora Kopparbergs Bergslags Ltd., Falun. A report is being prepared by C. Lundqvist. Comment (G.ö.) : three samples of this series have been listed previously (Stockholm I) and desc. by G. Lundqvist (1957). These age figures are now recalculated to NBS-scale and marked with an $n$ before the St-number.

$\begin{array}{llr}\text { n St-163. } & \text { Falun 1, peat } & 1050 \pm 60 \\ \text { St-557. } & \text { Falun 2, peat } & 840 \pm 85 \\ \text { St-556. } & \text { Falun 3, wood } & 1230 \pm 80 \\ \text { St-558. } & \text { Falun 4, wood } & 600 \pm 70 \\ \text { n St-165. } & \text { Falun 5, wood } & 635 \pm 55 \\ \text { n St-166. } & \text { Falun 7, wood } & 820 \pm 60 \\ \text { St-738. } & \text { Falun 9, peat } & 4220 \pm 105 \\ \text { St-684. } & \text { Krongården 1, wood } & 415 \pm 100 \\ \text { St-663. } & \text { Krongården 8, peat } & 4240 \pm 80 \\ \text { St-685. } & \text { Krongården 10, wood } & 390 \pm 70 \\ \text { St-664. } & \text { Krongården 11, peat } & 1605 \pm 65\end{array}$

B. Problems of Late Bronze Age-Early Iron Age

\section{Fiskeby and Horn series}

Resin caulkings from various grave fields in middle Sweden. Among them, the Fiskeby grave field forms a chronologic series of graves from the last phase of the Bronze Age to the second half of the Viking Age. The resin was used as tightening material in bark boxes filled with cremated bone. In addition, many of the graves contain only artifacts which cannot yet be dated archaeologically, but which are of importance for further work. In Sweden, however, there is a serious lack of archaeological material that can be connected with the first two periods of the Iron Age (500 to 100 в.c.). $\mathrm{C}^{14}$ dating of the caulkings may also indicate whether the break in the series of finds indicates an intermission in 
the use of the burial place, or is caused by other reasons. Samples were collected in 1951-1952 and subm. by P. Lundström, Mus. of National Antiquities, Stockholm. Descriptions have been made by Sahlström and Gejvall (1948, 1954) and the submitter (Lundström, 1952a, b). Some age figures belonging to this series have been published in previous dating lists of this Laboratory (Stockholm II and III). Because this extensive sample series is at least temporarily finished and the result is to be used by the submitter, previous dates are repeated here. These have been recalculated to be expressed in the internationally adopted NBS-scale. These samples have been marked with " $n$ " before the St-number.

\section{Fiskeby}

A grave field including 520 inhumations, located at Fiskeby $\left(58^{\circ} 36^{\prime} \mathrm{N}\right.$ Lat, $16^{\circ} 06^{\prime} \mathrm{E}$ Long), Ö. Eneby parish, Östergötland.

n St-317. Fiskeby 1, Grave no. 248

$2455 \pm 90$

n St-321. Fiskeby 2, Grave no. 217

$2450 \pm 85$

n St-326. Fiskeby 3, Grave no. 536

$1970 \pm 75$

n St-327. Fiskeby 4, Grave no. 556

$2015 \pm 85$

n St-385. Fiskeby 5, Grave no. 366

$1925 \pm 100$

n St-390. Fiskeby 7, Grave no. 317

$2580 \pm 90$

n St-405. Fiskeby 6 , Grave no. 7

$2085 \pm 140$

n St-481. Fiskeby 14, Grave no. 316

$2045 \pm 80$

n St-482. Fiskeby 13, Grave no. 290

$2065 \pm 110$

n St-483. Fiskeby 15, Grave no. 198

$1995 \pm 80$

n St-484. Fiskeby 16, Grave no. 414

$2280 \pm 85$

n St-505. Fiskeby 17, Grave no. 614

$1915 \pm 80$

n St-507. Fiskeby 19, Grave no. 283

$1875 \pm 80$

n St-509. Fiskeby 21, Grave no. 542

$2015 \pm 70$

n St-510. Fiskeby 22, Grave no. 681

$1885 \pm 60$

St-630. Fiskeby 44, Grave no. 143

$1945 \pm 70$

St-631. Fiskeby 43, Grave no. 117

$2020 \pm 70$

St-634. Fiskeby 42 , Grave no. 580

$2060 \pm 70$

St-638. Fiskeby 41, Grave no. 464

$1790 \pm 75$

St-639. Fiskeby 40, Grave no. 370

$2040 \pm 70$

St-646. Fiskeby 39, Grave no. 239

$2180 \pm 70$ 
St-649. Fiskeby 38, Grave no. 237

$2085 \pm 70$

St-650. Fiskeby 37, Grave no. $42 \quad 2320 \pm 90$

\section{Horn} land.

Grave field at Horn church $\left(58^{\circ} 31^{\prime} \mathrm{N}\right.$ Lat, $13^{\circ} 54^{\prime} \mathrm{E}$ Long), Västergöt-

n St-444. Horn 9, Grave no. 109

$2045 \pm 70$

n St-445. Horn 10, Grave no. 119

$2185 \pm 90$

n St-446. Horn 11, Grave no. 211

$1965 \pm 80$

St-590. Horn 23, Grave no. 77

$2200 \pm 100$

St-591. Horn 24, Grave no. 210

$1950 \pm 80$

St-592. Horn 25, Grave no. 205

$1970 \pm 85$

St-593. Horn 26, Grave no. 216

$2190 \pm 90$

St-594. Horn 27, Grave no. 41

$2160 \pm 110$

St-595. Horn 28, Grave no. 74

$2130 \pm 80$

St-596. Horn 29, Grave no. 207

$2020 \pm 85$

\section{Bankälla}

Location: Bankälla $\left(58^{\circ} 32^{\prime} \mathrm{N}\right.$ Lat, $13^{\circ} 56^{\prime} \mathrm{E}$ Long$)$, Välla parish, Västergötland.

n St-480. Bankälla 12, Grave no. 50

$$
\begin{aligned}
& 1910 \pm 75 \\
& 2240 \pm 90 \\
& 2190 \pm 80
\end{aligned}
$$

St-597. Bankälla 30, Grave no. 57

St-598. Bankälla 31, Grave no. 40

Rogsta Hage

Location: Rogsta Hage (58 $51^{\prime} \mathrm{N}$ Lat, $17^{\circ} 13^{\prime} \mathrm{E}$ Long), Tystherga parish, Södermanland.

n St-443. Rogsta Hage 8, Grave no. 24

$2415 \pm 100$

St-659. Rogsta Hage 33, Grave no. 31

$2480 \pm 100$

St-652. Vikingstad 36

$2030 \pm 90$

Location: Nybble $\left(58^{\circ} 23^{\prime} \mathrm{N}\right.$ Lat, $15^{\circ} 28^{\prime}$ E Long), Vikingstad parish, Östergötland.

St-653. Klockrike 35

$2405 \pm 100$

Location: Berga $\left(58^{\circ} 29^{\prime} \mathrm{N}\right.$ Lat, $15^{\circ} 21^{\prime} \mathrm{E}$ Long $)$, Klockrike parish, Östergötland.

St-657. Östra Huseby 34

$2160 \pm 70$

Location: Odensberget $\left(58^{\circ} 35^{\prime} \mathrm{N}\right.$ Lat, $16^{\circ} 34^{\prime} \mathrm{E}$ Long), Östra Huseby parish, Östergötland. 
St-660. Vreta Kloster 32

Location: Brunneby $\left(58^{\circ} 30^{\prime} \mathrm{N}\right.$ Lat, $15^{\circ} 30^{\prime} \mathrm{E}$ Long), Vreta Kloster parish, Östergötland.

\section{Persberg series}

Charcoal samples from one grave and one hearth at Persberg $\left(58^{\circ} 23^{\prime} \mathrm{N}\right.$ Lat, $13^{\circ} 05^{\prime} \mathrm{E}$ Long), Våmb parish, Västergötland. The constructions are situated on a grave field with large cairns containing burial remains from the Bronze Age to Roman Iron Age. The samples have been taken from two of the many cairns which lack archaeologic datable finds. Coll. 1957 by Ulla Silvén; subm. by Else Nordahl, Mus. of National Antiquities.

\section{St-741. Carin 2 T, hearth}

St-742. Cairn 2 D, cremation
$2165 \pm 100$

$2015 \pm 80$

$3095 \pm 105$

St-739. Igelsta 9

Charcoal from a cairn of brittle-burned stones at Igelsta $\left(59^{\circ} 11^{\prime} \mathrm{N}\right.$ Lat,
$40^{\prime}$ E Long), Östertälje parish, Södermanland. Judging from connected $17^{\circ} 40^{\prime} \mathrm{E}$ Long), Östertälje parish, Södermanland. Judging from connected
finds the construction should date from Late Bronze or Early Iron Age. Coll. 1958 by Birgitta von Heland; subm. by Else Nordahl. Comment (E.N.) : date is younger than expected. This will be investigated further.

\section{St-740. Åkerby}

$1580 \pm 90$

Resin caulkings from a grave at Åkerby $\left(59^{\circ} 40^{\prime} \mathrm{N}\right.$ Lat, $17^{\circ} 03^{\prime} \mathrm{E}$ Long), Vårfrukyrka parish, Uppland. The grave, no. 8 in a Bronze Age cemetery, apparently has been robbed and on excavation contained only the remains of a cremation burial from the Iron Age. Coll. 1959 and subm. by Else Nordahl.

\section{Bälinge series}

Resin caulkings from two graves at Högsta $\left(59^{\circ} 59^{\prime} \mathrm{N} \mathrm{Lat}, 17^{\circ} 71^{\prime} \mathrm{E}\right.$ Long), Bälinge parish, ca. $15 \mathrm{~km} \mathrm{~N}$ of Uppsala, Uppland. Of ca. 40 graves, ca. 10 could be dated by metal finds to between 1,000 and 0 B.c. Many of the undated graves seem to belong to the same time periods. Samples are taken from this group. Coll. 1955 and subm. by Margareta Biörnstad, Royal Office of Antiquities (Biörnstad, 1960).

\section{St-503. Bälinge Grave no. 4$$
2070 \pm 80
$$ \\ St-504. Bälinge Grave no. 11 A \\ $2080 \pm 100$}

\section{Various Archaeological Samples, Sweden, except Lappland}

\section{Skedemosse series, öland}

Wood samples from a drained fen, Skedemosse $\left(56^{\circ} 05^{\prime} \mathrm{N}\right.$ Lat, $16^{\circ} 45^{\prime} \mathrm{E}$ Long), Gärdslösa parish, öland, coll. from different layers and constructions in the fen. The normal profile has a total depth of ca. $100 \mathrm{~cm}$ subdivided as follows: Cultivated layer/Peat/Algal gyttja/Lime gyttja/Sand/Layer of stumps, logs and coarse detritus/Gravel. In the Algal gyttja have been found 
sacrificial finds consisting of partly destroyed jewellery, weapons and bones of animals and human beings, datable to the 4th and 5th centuries A.D. It is comparable with well-known finds in Danish bogs, even surpassing them in its richness in gold. In the same layer were found floats and fish-hooks. Fishing activity is also shown by two fish weirs. The best-preserved one, from which samples St-618 and 619 were collected, is of a type well-known from ethnographical material, but unknown in prehistoric contexts. The construction of these fish weirs precludes any dating other than by $\mathrm{C}^{14}$. Site is described by U. E. Hagberg 1961 and 1962. Coll. 1959 and 1960 and subm. by U. E. Hagberg, Royal Office of Antiquities.

St-518. Skedemosse 18

$9200 \pm 160$

Stick in the stump layer, $70 \mathrm{~cm}$ below surface.

St-519. Skedemosse 10

$2300 \pm 80$

Stick in the algal gyttja, $30-35 \mathrm{~cm}$ below surface.

St-618. Skedemosse 223

$3270 \pm 90$

Laths from the catchholder of a "northern" fish weir.

St-619. Skedemosse 223: XIX

$3410 \pm 100$

Stake from "northern" fish weir.

St-620. Skedemosse 300

$3350 \pm 90$

Laths from "southern" fish weir.

St-662. Skedemosse 302

$2505 \pm 70$

Bark float between algal gyttja and lime gyttja ca. $35 \mathrm{~cm}$ below surface.

St-665. Skedemosse 317

$3475 \pm 100$

Bark float in peat $25 \mathrm{~cm}$ below surface.

St-603. Västra Älten

Wood from a dugout canoe found in Lake Västra Älten $\left(56^{\circ} 24^{\prime} \mathrm{N}\right.$ Lat, $15^{\circ} 30^{\prime}$ E Long), Möllekulla, Tving parish, Blekinge. Canoe, made of an oak $\log$, was found at the shore on the lake bottom partly covered by gyttja (water depth $0.5 \mathrm{~m}$ ). Sample was taken from the outer annual rings. It was not possible to make a geologic or archaeologic dating. Dug-out canoes are known to have been used very late in lakes of southeastern Sweden. Coll. and subm. by B. E. Berglund, Dept. of Quaternary Geol., Univ. of Lund. Comment (G.ö.) $: 2 \sigma$ confidence (97\%) in age figure $\sigma=80$. (B.E.B.) : $\mathrm{C}^{14}$ dating confirms the assumption that the boat was very young.

St-605. Lörby

$\mathbf{3 1 5} \pm \mathbf{8 0}$

Wood from a dug-out canoe found in the Baltic Sea, Lörby $\left(56^{\circ} 05^{\prime} \mathrm{N}\right.$ Lat, 14 ${ }^{\circ} 44^{\prime} \mathrm{E}$ Long), Mjällby parish, Blekinge. The canoe, made of a beech $\log$, was found on the sea bottom almost completely covered by sand (water depth 5-6 m) ca. $200 \mathrm{~m}$ from the shore. Sample was taken from the outer annual rings. It was not possible to make a geologic or archaeologic dating. 
Coll. and subm. by B. E. Berglund. Comment (B.E.B.) : $\mathrm{C}^{14}$ dating indicates that dug-out canoes occurred rather late at the sea coast of Blekinge.

St-661. Äskekärr

$1120 \pm 75$

Cattle hair from clinker-built ship of Viking type, found at Göta Älv River at Äskekärr $\left(57^{\circ} 56^{\prime} \mathrm{N}\right.$ Lat, $12^{\circ} 04^{\prime} \mathrm{E}$ Long $)$, Starrkärr parish, Västergötland. The ship was excavated in 1933. Sample subm. by C.-A. Moberg, Archaeol. Mus., Göteborg.

\section{St-577. Vallhagar}

$1800 \pm 85$

Resin calkings from a grave in the large crematory grave field of Vallhagar ( $57^{\circ} 20^{\prime} \mathrm{N}$ Lat, $18^{\circ} 13^{\prime} \mathrm{E}$ Long), Fröjel parish, Gotland. In 1946-1949 this site, hitherto the largest migration period settlement of the North (25 house grounds), was excavated as an international team work (Stenberger et al., 1955). The grave contains an unburnt skeleton, and connected finds date it to the 1st or 2nd century A.D. Coll. 1959 and subm. by E. Nylén, Gotlands Fornsal, Visby.

\section{Resin cakes series}

Finds of a particular type of resin cake, subm. by M. P. Malmer, Mus. of National Antiquities. Approximate archaeological dating is Bronze Age, but closer date is desirable.

\section{St-690. Vittened}

Pieces of resin cake founde connected with probable Late Neolithic tools at Vittened $\left(58^{\circ} 15^{\prime} \mathrm{N}\right.$ Lat, $12^{\circ} 45^{\prime} \mathrm{E}$ Long), Högarne, N. Björke parish, Västergötland, in a layer of gyttja on sand, at depth of $1.4 \mathrm{~m}$ in a peat bog. Coll. 1929 by K. and S. Levin. The tools have been described by A. Oldeberg (1932).

\section{St-514. Tågarp 7}

$\mathbf{2 8 0 0} \pm \mathbf{8 0}$

Two resin cakes found A.D. 1845 together with 12 others of similar type in the Orbyngs-bog, Tågarp $\left(55^{\circ} 30^{\prime} \mathrm{N}\right.$ Lat, $13^{\circ} 15^{\prime} \mathrm{E}$ Long $)$, V. Tommarp parish, Skåne.

\section{St-515. Borrby}

$2770 \pm 100$

Five resin cakes and fragments of a sixth found A.D. 1806 in a bog in Borrby parish $\left(55^{\circ} 20^{\prime} \mathrm{N}\right.$ Lat, $14^{\circ} 07^{\prime} \mathrm{E}$ Long), Skåne.

\section{St-513. Bergstena}

$400 \pm 85$

Wood from a cellar construction at one of the oldest farms in W Sweden, situated in Kolbäck ( $58^{\circ} 04^{\prime} \mathrm{N}$ Lat, $12^{\circ} 38^{\prime} \mathrm{E}$ Long), Bergstena parish, Västergötland. Construction material was taken from a Swedish stave church in the middle of the 19th century. The church is believed to have been built during the Medieval Period. Subm. by S. A. Hallbäck, The Vänersborg Mus., Vänersborg.

\section{St-516. Drottningholm}

$$
1580 \pm 85
$$

Wood from a wooden structure, found A.D. 1959 in a chieftain's grave from the Iron Age cemetery at Viken (59 $19^{\prime} \mathrm{N}$ Lat, $17^{\circ} 53^{\prime} \mathrm{E}$ Long), close 
to the castle of Drottninholm, $10 \mathrm{~km} \mathrm{~W}$ of Stockholm. The grave had been robbed in an earlier time. Collected during excavations led by Greta Arwidsson, Dept. of Northern Archaeol., Stockholm Univ. and subm. by her.

\section{Dragby series}

Resin and charcoal from a large prehistoric cemetery at Dragby $\left(59^{\circ} 59^{\prime}\right.$ $\mathrm{N}$ Lat, $17^{\circ} 35^{\prime} \mathrm{E}$ Long), Skuttunge parish, Uppland. The field includes ca. 330 visible constructions belonging to one continuous series, or possibly two periods, from Late Neolithic to early Roman Iron Age. Coll. 1960 by S. Rydh and Ulla Silvén; subm. by M. Stenberger, Inst. of Scandinavian Archaeol., Uppsala Univ. Other samples have been dated by Olsson (Uppsala I and II). Site is described by Stenberger (1960) and others.

St-698. Dragby 162 B

$$
\mathbf{2 2 9 0} \pm \mathbf{9 0}
$$

Resin from a grave on lower level.

St-699. Dragby 331

$2425 \pm 80$

Charcoal from same level as St-698.

St-700. Dragby $88 \mathrm{P}$

$3175 \pm 80$

Charcoal on top of latest entombed bodies in a megalithic stone cist.

\section{St-703. Dragby 88 U}

$3255 \pm 80$

Charcoal from a hearth stratigraphically belonging to same period as megalith tomb.

St-701. Dragby $88 \mathrm{M}$

$\mathbf{2 4 7 0} \pm \mathbf{8 0}$

Charcoal above peat layer (old ground surface) on top of gravel filling of the megalith tomb.

\section{St-702. Dragby 88 Q}

$$
\mathbf{2 7 8 0} \pm \mathbf{8 0}
$$

Charcoal from a cremation presumably belonging to same period as $88 \mathrm{M}$, definitely younger than $88 \mathrm{U}$.

\section{St-704. Dragby $88 \mathrm{~S}$}

$\mathbf{3 1 4 5} \pm \mathbf{1 3 0}$

Charcoal underlying a grave possibly belonging to same period as $88 \mathrm{M}$.

\section{Högom series}

Birch bark and charcoal from postholes of a house, underlying a grave mound from the 6th century A.D. at Högom $\left(62^{\circ} 24^{\prime} \mathrm{N}\right.$ Lat, $17^{\circ} 16^{\prime} \mathrm{E}$ Long $)$, $\mathrm{N}$ of Sundsvall, Selånger parish, Medelpad. The house, which may be one of the oldest excavated in northern Sweden, could not be dated with artifacts but must be older than the grave for stratigraphic reasons. Coll. 1956 and subm. by Margareta Biörnstad.

\section{St-586. Högom 1}

$$
1535 \pm 90
$$

Birch bark from vertical posthole.

\section{St-587. Högom 2}

Birch bark from vertical posthole.

$$
1450 \pm 80
$$


St-588. Högom 3

$1610 \pm 85$

Charcoal from hole with vertical post.

St-589. Högom 4

$1650 \pm 80$

Charcoal from horizontal beam.

Comment (M.B. and G.ö.) : the slightly older values for the charcoal samples probably reflect a reasonable growth time for the wood.

\section{Lossnen series}

Resin calkings from two graves in a grave field at Smalnäset, Lake Lossnen ( $62^{\circ} 25^{\prime} \mathrm{N}$ Lat, $12^{\circ} 51^{\prime} \mathrm{E}$ Long), Tännäs parish, Härjedalen. The place is a small peninsula containing 36 inhumations. Some of the graves contain only metal artifacts which cannot yet be dated archaeologically. There were also some stone artifacts in two graves. The resin was used as tightening material in bark boxes filled with cremated bone. Coll. and subm. by H. Hvarfner, Royal Office of Antiquities.

\section{St-511. Lossnen 3$$
2070 \pm 90
$$ \\ St-512. Lossnen 17 \\ $2060 \pm 75$}

\section{Archaeology of Lappland}

\section{Umnässjön series}

Samples from a site situated on one side of a small low peninsula in the upper part of Lake Umnässjön ( $65^{\circ} 24^{\prime} \mathrm{N}$ Lat, $16^{\circ} 03^{\prime} \mathrm{E}$ Long), Stensele parish, Lappland. Among the finds of the usual stone age character were two strike-a-light stones of Iron Age type. Coll. 1958 by Elisabeth Allard; subm. by H. Hvarfner and Elisabeth Allard.

St-743. Umnässjön 1

$1660 \pm 105$

Charcoal from heavy trunks or branches in a cooking pit $2 \mathrm{~m}$ from the shoreline.

St-744. Umnässjön 2

$1625 \pm 100$

Charcoal from small twigs and bark in the sand wall around the same cooking pit. One fragmentary quartz spear head was found with the charcoal layer.

St-745. Umnässjön 3

$1040 \pm 80$

Charcoal, partly mixed with sand from Hearth no. 8 at the shoreline.

St-746. Umnässjön 4

$\mathbf{8 5 0} \pm \mathbf{8 0}$

Similar to St-745 but from Hearth no. 9 .

\section{Döudden series}

Charcoal from a site at Döudden $\left(66^{\circ} 04^{\prime} \mathrm{N}\right.$ Lat, $18^{\circ} 09^{\prime} \mathrm{E}$ Long), Stensund, at Lulepotten Bay in Lake Hornavan, Arjeplog parish, Lappland. The place is a small peninsula formed by drifting sand, bound by vegetation and contains several culture levels. Lower levels contain stone artifacts only, but 
the upper levels also contain pottery. Coll. 1958 by Birgitta Hallgren and G. Östlund; subm. by H. Hvarfner and B. Hallgren. Dates in this series were published (Stockholm III) under the name Hornavan series. See Hallgren, 1959. A comprehensive description is being prepared by her. Previous dates are also repeated here, recalculated to the NBS-scale, and marked with $n$ before the St-number.

\section{Profile 10}

n St-454. Döudden 2

$1865 \pm 80$

Thin, extensive layer of charcoal, on this point covered by $70 \mathrm{~cm}$ of sand up to base of present-day vegetation. Sample was located just on top of the uppermost reliable cultural layer.

St-547. Döudden 3

$3200 \pm 100$

Charcoal layer ca. $20 \mathrm{~cm}$ below the layer with sample St- 454 .

St-548. Döudden 4

$5200 \pm 150$

Lowest charcoal layer, here ca. $40 \mathrm{~cm}$ below sample St-454.

\section{Profile 9}

n St-455. Döudden 5

$1655 \pm 70$

Stratigraphically the same layer as St -545 but $5 \mathrm{~m}$ from that point. Here covered by sand $25 \mathrm{~cm}$ thick.

St-549. Döudden 6

$3815 \pm 85$

Thin charcoal layer ca. $30 \mathrm{~cm}$ below the layer with sample St-455.

St-550. Döudden 7

$5070 \pm 125$

Lowest charcoal layer ca. $20 \mathrm{~cm}$ below St-549.

St-551. Döudden 8

$5050 \pm 120$

Same layer as St-550.

Additional samples

n St-457. Döudden 13

$1755 \pm 75$

Same layer as St-454 and St-455.

St-553. Döudden 15

$3560 \pm 85$

Intermediate charcoal layer containing asbestos pottery.

St-552. Döudden 14

$\mathbf{5 1 0 0} \pm \mathbf{8 5}$

Charcoal connected with a quartzite scraper situated below brittle-burned stones in lowest layer.

n St-453. Döudden 1

$6105 \pm 100$

Charcoal from hearth in lowest layer. Cf dates on sifted samples St-453 A, F, C in Stockholm III. 
n St-456. Döudden 11

$6115 \pm 100$

Charcoal from another hearth at the same stratigraphic position as St-453. At least one stone scraper was found definitely related to the hearth.

\section{Varghalsen series}

Samples from site at Varghalsen on island of Galtisguts $\left(66^{\circ} 04^{\prime} \mathrm{N}\right.$ Lat, $17^{\circ} 54^{\prime}$ E Long), in SE part of Lake Hornavan, Arjeplog parish, Lappland. Site is partly covered by sand dunes on the beach, and by a small moor inside the dunes. Coll. 1960 by Birgitta Hallgren and B. O. H. Johansson; subm. by H. Hvarfner and B. Hallgren.

St-691. Varghalsen 3

$875 \pm 70$

Charcoal layer, containing quartzite artifacts and imbedded in podzol. Location T 112.

St-693. Varghalsen 5 a

$1675 \pm 80$

Highly humified peat layer indicating old ground surface, containing asbestos pottery, now covered with sand. Location W 24.

St-695. Varghalsen 5 c

$1110 \pm 70$

Stratigraphically the same layer as St-693. Location X 22.

St-696. Varghalsen 33

$620 \pm 65$

Peat sample from the moor, 25-27 cm below surface. Location AO 45.

\section{St-692. Varghalsen 34}

$1840 \pm 75$

Peat $8 \mathrm{~cm}$ below St-696. Location AO 45.

St-697. Varghalsen 35

$4380 \pm 85$

Peat $41-42 \mathrm{~cm}$ below surface and $8 \mathrm{~cm}$ below St-692. The layer contains Hearth no. 23. Location AO 45.

\section{E. Younger Laponian Cultures}

All samples subm. by E. Manker, Nordic Mus., Stockholm.

St-721. Vuollerim

$310 \pm 95$

Fragment of a wooden sledge (akja) from a grave at ca. $0.5 \mathrm{~m}$ depth. Find was made at Vuollerim (66 $26^{\prime} \mathrm{N}$ Lat, $20^{\circ} 57^{\prime} \mathrm{E}$ Long), Jokkmokk parish in the 1930's and sent to the Museum in 1945.

\section{St-760. Njuovvo-vierah}

$\mathbf{3 0 0} \pm \mathbf{8 0}$

Fragment of a wooden coffin found at Njuovvo-vierah $\left(66^{\circ} 36^{\prime} \mathrm{N}\right.$ Lat, $17^{\circ} 52^{\prime} \mathrm{E}$ Long), near Njuorvajokk, where a small stream is crossed by the migration path between Gardeks and Palkesnjuonje Lapp camps, Arjeplog parish. Coll. 1959 by B. Sommarström.

\section{St-722. Kallaksundet}

$215 \pm 60$

Fragment of a child's wooden coffin, found under a block of stone at the Kallaksundet $\left(66^{\circ} 32^{\prime} \mathrm{N}\right.$ Lat, $17^{\circ} 41^{\prime}$ E Long), between Lake Tjeggelvas and 
Lake Skärfajaure, Arjeplog parish. Coll. 1943 and sent to the Museum the same year.

St-730. Tjatjetievva

Hair from reindeer skin found in an akja used as coffin which was placed in a grave, about $80 \mathrm{~cm}$ deep in a dry heap of earth, Tjatjetievva $\left(66^{\circ} 02^{\prime} \mathrm{N}\right.$ Lat, $15^{\circ} 31^{\prime}$ E Long), a marshy district ca. $4 \mathrm{~km}$ north of Lake Tärnasjön's northern end, Tärna parish. Coll. 1953 by E. Manker during the Museum's field research. Comment (G.ö.) : $2 \sigma(97 \%)$ confidence in the age limit figure. $\sigma=80 \mathrm{yr}$.

St-759. Guttuberget

$\mathbf{5 0 0} \pm \mathbf{9 0}$

Fragment of birch bark, used as grave clothes. The find was made in a stone coffin-shaped grave at the slope of Guttuberget Mountain $\left(65^{\circ} 39^{\prime} \mathrm{N}\right.$ Lat, $15^{\circ} 31^{\prime}$ E Long), near Forsbäck, Tärna parish. Coll. 1923 and sent to Mus. of National Antiquities.

\section{GEOCHEMICAL SAMPLES AND DEEP-SEA CORES}

\section{Havtjärnheden series}

Soil humus from a profile in a very poor pine forest, ca. $130 \mathrm{yr}$ old, on strongly podzolized moraine (formed from sandstone and porphyr) at Havtjärnheden $\left(61^{\circ} 21^{\prime} \mathrm{N}\right.$ Lat, $13^{\circ} 29^{\prime} \mathrm{E}$ Long $)$, Älvdalen parish, Dalarna. Atl ca. 500 m. Coll. 1959 and subm. by C. O. Tamm, Forest Research Inst., Stockholm.

\section{St-576. 5006}

$$
\begin{array}{cr}
\Delta \quad \% 0 & \text { Formal age } \\
-\mathbf{1 7} \pm \mathbf{6} & \mathbf{1 4 0} \pm \mathbf{8 0}
\end{array}
$$

Transitional horizon between mor (raw humus) layer and mineral soil $\left(\mathrm{A}_{1}\right.$ with some $\mathrm{A}_{\mathrm{o}}$ ). Ash content $81.6 \%$ of dry weight.

St-580. $\quad 5007$

$$
-28 \pm 8 \quad 230 \pm 85
$$

Leached horizon $\left(A_{2}\right)$. Ash content $96.1 \%$ of dry weight.

\section{St-575. 5008 B}

$$
-49 \pm 6 \quad 400 \pm 80
$$

Accumulation horizon $\left(B_{1}\right.$ with some $\left.B_{2}\right) . B_{1}$ is a very dark-brown hardpan. Ash content $89.2 \%$ of dry weight. Comment (G.ö.) : error in $\Delta$ for comparison within this series only. Error in age figures is total error.

General Comment (C.O.T.) : this series parallels the Garpenberg series St-472, 473, and 474, (Tamm and Östlund 1960), but is from a much poorer site. The $\mathrm{C}^{14}$-content of organic matter in the hardpan corresponds to a formal age of $400 \pm 80 \mathrm{yr}$, which is approx. the same as in B-horizon humus in sample St-474. B-horizon organic matter from a humus podzol in the Netherlands has been dated to $940 \pm 20 \mathrm{yr}$ (sample L-25l in Lamont III). The A-horizon organic matter (St-575 and St-576) is younger and cannot be safely dated, but the figures suggest that a considerable part of the humus is older than the present forest generation at Havtjärnheden. This is in contrast to the results from Garpenberg. 


\section{Albex series}

Eight samples of Globigerina ooze and detrital Globigerina mud, from deep-sea cores nos. 224 and 225 collected off $W$ coast of Africa by the Albatross Expedition (Alb-ex), the Swedish Deep Sea Expedition 1947-1948. Subm. by Ulla Regnell, Dept. of Mineral. and Geol., Univ. of Lund. Only carbonate fraction used. Core 224 was taken at depth of $2810 \mathrm{~m}\left(18^{\circ} 50^{\prime} \mathrm{N}\right.$ Lat, $18^{\circ}$ $24^{\prime}$ W Long). Core 225 was taken at depth of $2978 \mathrm{~m}$ ( $18^{\circ} 44^{\prime} \mathrm{N} \mathrm{Lat}, 18^{\circ} 44^{\prime}$ W Long). Levels are given in $\mathrm{cm}$ below sediment surface.

St-559. Albex 1

$7940 \pm 140$

Core 224 Level 98-99, grain size $>150 \mu$.

St-560. Albex 2

$8200 \pm 110$

Core 224 Same level, grain size $<150 \mu$.

St-561. Albex 3

$14,920 \pm 300$

Core 224 Level 252-264 cm.

St-562. Albex 4

$\mathbf{2 4 , 1 7 0}+\mathbf{9 5 0}$

Core 224 Level $410-423 \mathrm{~cm}$.

St-666. Albex 5

$6375 \pm 90$

Core 225 Level $42-50.5 \mathrm{~cm}$.

St-667. Albex 6

$23,020 \pm 450$

Core 225 Level $289-301 \mathrm{~cm}$.

\section{St-667. Albex 7}

$\mathbf{3 7 , 0 0 0}+\mathbf{3 0 0 0}$

Core 225 Level $395-407 \mathrm{~cm}$. Comment (L.E.) : age $+2 \sigma$ is equivalent to $45,000 \mathrm{yr}$. Residual activity is $(1.0 \pm 0.3) \%$ of standard NBS or $\Delta=-990$ \pm 3 .

St-669. Albex 8

$>40,000$

Core 225 Level $558-571 \mathrm{~cm}$. Comment (L.E.) : 3 o confidence.

General Comment (G.ö.) : dates are $\mathrm{C}^{14}$-time elapsed since the material was in solution at the sea surface, i.e. $\delta \mathrm{C}^{13}$ corrected age minus $400 \mathrm{yr}$. Cf. Intro. to Miami I.

\section{REFERENCES}

Date lists:

Lamont III Broecker, Kulp, and Tucek, 1956

Miami I Östlund, Bowman, and Rusnak, 1962

Stockholm I Östlund, 1957

Stockholm II Östlund, 1959

Stockholm III Östlund and Engstrand, 1960

Uppsala I Olsson, 1960

Uppsala II Olsson, 1961

Biörnstad, M., 1960, Gravfält och vallanläggning vid Högsta i Bälinge: Tor, v. 6, p. 125.

Broecker, W. S., Kulp, J. L., and Tucek, C. S., 1956, Lamont natural radiocarbon measurements III: Science, v. 124, p. 162. 
Brotzen, F., 1961, An Interstadial (radiocarbon dated) and the substages of last glaciation in Sweden: Geol. fören. Stockholm Förh., v. 83, p. 144-150.

Craig, Harmon, 1961, Mass-spectrometer analyses of radiocarbon standards: Radiocarbon, v. 3, p. $1-3$.

Donner, J., 1957, The post-glacial shore-line displacement in the Kuopio district: Acad. Sci. Fennicae Annales ns. A, III, Geol.-Geog. 49, 34 p.

Fries, M., 1962, Studies of the sediments and the vegetational history in the Ösbysjö basin, north of Stockholm: Oikos, v. 13, in press.

Hagberg, U. E., 1961, Skedemoss första presentation: Fornvännen, v. 56, p. 237-255 [mit Deutsche zusammenfassung].

1962, Fiskewatsan idag och för 3500 år sedan: Tor, v. 8, p. 229-243 [mit Deutsche zusammenfassung].

Hallgren, Birgitta, 1959, Döuddenwen lapsk järnåldersboplats: Norrbotten 1959 [Yearbook], Norrbottens Läns Hembygdsförening, Luleå, p. 113-120.

Kanto Loam Research Group, 1961, On the geological age of the Hanaizumi bed . . . Earth Sci. [Japan], v. 53, p. 28-31.

Kotilainen, M. J., 1953, Hiekkakerroksen alle peittynyt muinaissuo Kuopion yläkaupungilla: Geologi, v. 5 , no. 8.

Lundqvist, G., 1957, C $\mathrm{C}^{14}$ analyser i svensk kvartärgeologi 1955-1957: Sveriges Geol. Undersökning ser. C, no. 557 [English summary].

1959, $\mathrm{C}^{14}$-dated pine stumps from the high mountains of western Sweden: Sveriges Geol. Undersökning, ser. C, no. 565, [in Swedish, English summary].

Lundström, P., 1952a, Gravfältsundersökningar vid Fiskeby 1951: Fornvännen, v. 47, p. 120.

1952b, Gravfältsundersökning vid Fiskeby 1952: Fornvännen, v. 47, p. 281.

Okko, V., 1948, On the development of the Heposuo bog, near the town of Kuopio: Comm. geol. Finl. Bull., v. 142, p. 21.

1960, The age of the subfossil roots of Alnus Glutinosa, Tuusula, Southern Finland: Comm. geol. Finlande Bull., v. 188, p. 9.

Oldeberg, A., 1932, The earliest history of the sickle: Acta Archaeol., v. 3, p. 221.

Olsson, Ingrid, 1960, Uppsala natural radiocarbon measurements I: Am. Jour. Sci. Radioc. Supp., v. 2, p. 126. 1961, Uppsala natural radiocarbon measurements II: Am. Jour. Sci. Radioc. Supp., v. 3, p. 84.

Östlund, H. G., 1957, Stockholm natural radiocarbon measurements I: Science, v. 126, p. 493-497.

1959, Stockholm natural radiocarbon measurements II: Am. Jour. Sci. Radioc. Supp., v. 1, p. 35-44.

Östlund, H. G., and Engstrand, L. G., 1960, Stockholm natural radiocarbon measurements III: Am. Jour. Sci. Radioc. Supp., v. 2, p. 186-196.

Östlund, H. G., Bowman, A. L., and Rusnak, G. A., 1962, Miami natural radiocarbon measurements I: Radiocarbon, v. 4, p. 51-56.

Persson, G., 1962, En transgressionslagerföljd från Limhamn: Geol. fören. Stockholm Förh., v. 84, p. 47-55 [English summary].

Sahlström, K. E., 1954, Bankälla och Stora Ro, Två västgötska brand-grops gravfält: Kungl. Vitterhetsakad. Handl. no. 89.

Sahlström, K. E., and Gejvall, N. G., 1948, Gravfältet på Kyrkbacken i Horns socken, Västergötland: Kungl. Vitterhetsakad. Handl. no. $60: 2$.

Sauramo, M., 1954, Das Rätsel des Ancylussees: Geol. Rundschau, v. 42, p. 197-233.

1958, Die Geschichte der Ostsee: Acad. Sci. Fennicae Annales, S A, III:51.

Stenberger, M., et al., 1955, Vallhagar, a migration period settlement on Gotland, Sweden: Almqvist et Wiksell [distrib.], Stockholm.

Stenberger, M., 1960, Gravfältet vid sockenmötet. Dragby i Skuttunge, orientering och problem: Tor, v. 6, p. 63-86.

Tamm, C. O., and Östlund, H. G., 1960, Radiocarbon dating of soil humus: Nature, v. 185, p. $706-707$. 